\title{
NCOA4/RET Fusion Gene
}

National Cancer Institute

\section{Source}

National Cancer Institute. NCOA4/RET Fusion Gene. NCI Thesaurus. Code C99847.

A fusion gene that results from a paracentric inversion inv(10)(q11q11) which fuses the $5^{\prime}$ portion of the NCOA4 gene and the 3' portion of the RET gene. This rearrangement is associated with papillary thyroid carcinoma. 